\title{
From an Erotic Couple to the Reference of Post Communist Tyranny and the Politics in Balkan: The Accident; Ismail Kadare
}

\author{
PhD Viola Isufaj \\ University of Tirana, Faculty of History and Philology \\ Department of Literature, Tirana, Albania
}

PhD Candidate Odhise Argjiri

Albanian Academy of Armed Forces, Military University Skanderbeg

Tirana, Albania

\section{Doi:10.5901/ajis.2013.v2n9p736}

\section{Abstract}

The suspicion and mystery of an erotic couple, whose taxi overturns on their way to the airport killing them both and the other disturbing questions about this tragic event go deeply to dark nightmarish allegory and reference of post communist tyranny and the politics in Balkan-which is the aim of this analyze. It seems that this roman makes sense on a historical plane and interpretation is linked with political, ideological and social aspect of the actuality. Thus, sometimes associated with Russian formalism, we are operating somewhere between it and structural and constructivist approach to discourse. Emphasizing historical, cultural and social specificity in this text, we are operating especially with Bakhtin's theory. Besfort $Y$, was employed by the Council of Europe as an analyst on Balkan affairs, so were their deaths - an accident or a double murder? Perhaps a suicide pact? The investigations involve both Serbian and Albanian intelligence (as Besfort may have been implicated in the decision to bomb Serbia and was preparing a secret mission to The Hague dealing with war crimes. He had also made remarks about Israel.) Rovena is always tempted like Balkan, and like Balkan she is always in the midst of fog; also like her country, Albania which had came out from a communist tyranny, she loved and longed for freedom, but who can evaluate or know what freedom is after a slavery? Besfort is seductive like Europe, pale like the race of murderers- he behaves like a dictator, - so it's an allegory of dictature in Hoxha regime that goes beyond this with larger significance.

Keywords: reference, allegory, erotic, politics

Eros-the consent to life in the bosom of death! How can we not evoke Georges Bataille, while talking about Eros and Thanatos and as the eroticism is said to be in essence the domain of violence and murder, execution.

The Accident should not be read only through its text, but also through its context.

When Rovena with her disordered passion turns out to be enigmatic and Besfort as well, the politics of the Balkans turns out to be enigmatic too!

Violence, passion and disorder can only put so strange things in the game! Slavishly in thrall to Besfort with her feverish and dark beauty, she hates this dependence but she is fatally addicted to it in the same time. We never know what this violence is, what unnamed longing and desire is associated with it!

There are not promises and hopes of future happiness. Their passion is suffering.

Also the accident in their taxi finds no rational explanation. It remains unexplained even in the last pages of the novel.

The dialogic nature of consciousness is the dialogic nature of human life itself. The single adequate form for verbally expressing authentic human existence is the open-ended dialogue. Life by its very nature is dialogic. To live means to participate in dialogue: to ask questions, to heed, to respond, to agree, and so forth. In this dialogue a person participates wholly and throughout his whole life: with his eyes, lips, hands, soul, spirit, with his whole body and deeds. He invests his entire self in discourse, and this discourse enters into the dialogic fabric of human life, into the world symposium" (Bakhtin,1984, p.293).

Actually, the fog of this erotic couple and the slavish dependence of Rovena reveal the slavish independence of Albania to other countries; their mist atmosphere and their crises reveals the mist of Balcans and the crisis that enveloped in the Balkans in the 1990s. It is also with Hoxha tyranny that the allegory deals-and with his enslaved people. 
While at the same time punitively rebellious, Rovena suffers so much in her desperation, there is again a reference to our nation's agony under the wonky totalitarianism of Enver Hoxha, and then, to the unnamed shock of post-totalitarism.

We can see that the author' $s$ intention is always there, visible and invisible- in both forms.

Two extreme polemical positions on interpretation, intentionalist and unintentionalist, can be opposed to each other as they are in the controversary poles between Barthes and Picard's: (Compagnon, 2004, p. 54)

1. It is necessary and sufficient to look in the text what the author meant to say, "his clear and lucid intention," as Picard said; that is the only criterion for the validity of the interpretation.

2. One never finds in the text anything but what it is telling (us), independently of its author's intentions, there are no criteria for the validity of interpretation.

Compagnon would like to try to extricate himself from the trap of the absurd alternate between objectivism and subjectivism, or between determinism and relativism, and to show that intention is indeed the only conceivable criterion for the validity of interpretation, but it is not the same as "clear and lucid" premeditation. So the alternatives above could be rewritten as follows:

1. we can search in the text for what it says with reference to its own context of origin (linguistic, historical and cultural)

2. we can search in the text for what it says with reference to the contemporary context of the readers.

These two theses are no longer not mutually exclusive, but on the contrary, complementary, they lead us to a form of the hermeneutic circle linking pre-comprehension and comprehension and postulate that if one cannot be wholly penetrated, he can at least be somewhat understand. (Compagnon, 2004, p. 55)

Between the two, however, testimonies of intention and the evidence of the text other information is situated between the text and the context, such as the language of the text, the meaning of words for an author and his contemporaries. (Compagnon, 2004, p 56)

This erotic story of this novel is situated in the background of protests Albanian Serbian children died under the bombardment of Americans -the identification of the meaning, the literary interpretation is linked here with the intention of the author: if meaning is intentional, objective, historical, there is no more need for the theory of the death of the author (the thesis of the death of author is known).

Other links: Balkan is tempting, misty, confused as Rovena / Euridice. Besfort is attractive, dominant, hard, handsome as the killers are, but overpowering like Europe. In these common attributes and in the harsh allusions to sex there is a similarity, an analogy.

In Graz, Rovena felt for the first time "the chains" of Besfort. But she considered herself a slave. She thought he loved her entirely for themselves, as any tyrant. As Kadare writes, "but this is not the first time in history that a savior was taken to a tyrant, tyranny taken as liberator"-and here the reference is explicit and evident. You cannot understand where the game ends and where the revenge start until they agree again to put other elements in game and they start talking to each other as client and motels girl.

There is a complaint that she not free and then a complaint that she has too much freedom. Besfort is the new freedom of which Rovena is addictive, as the new freedom that came in Albania after totalitarian regime. We can see in politics as in an erotic couple, freedom, slavery and addiction are so close to each other as can easily be confused.

So these are the attractions, addictions, madness of the new post-communist tyranny with its roots to the former tyranny: the communist one. From it, they derive.

The couple met while experiencing freedom that was inconceivable at the time of communism. (The diplomatic trips of Besfort during which they experienced freedom without knowing what the immediate freedom is, are perhaps the itinerary of a"spy".) So they and their love affair are moving in both systems.

The confusion is especially born because totalitarianism will always fail to deal with some non-ideological private things, as sex or erotic libido-but on the other side Eros can not attain perfection without violation. What is especially needed to revolutionize in communism is sex and the beauty! But this is against their program. Can anybody or anything make a resistance like that? Who can prevent himself without consequences from erotic libido? Thus, Rovena and Besfort relation is contaminated by ideology and politics of communism, or better to say, much more by its results, and is also now trapped in the joints of capitalism even the appearance of their bodies, submissive and dominant, is thus determined.

Besfort tells Rovena of when he was only 13 years old, at the end of the dictatorship, a kind of madness that had appeared under Hoxha. He describes a world which citizens (each of them more miserable than the other) would claim that they are conspirators, in order to show love for the leader, being punished for crimes they did not do.

No one could distinguish truth from fiction regarding these reports, as it was impossible excelled what was the purpose of the conspirators, or its leader. Sometimes it was easy to read the mind of the leader. He had enslaved nation 
and now all conspirators will worship his crowning triumph. Some people say that he was fed up with the love of faithful followers and wanted something new and seemingly impossible-"love traitors ".

Besfort is thus, a victim of totalitarianism, which he despises, he can not escape his deformities, heritage, memories, hysteria-that how dictatorship has affected him.

But even a melancholy thought appears in the background. Kadare with the fall of communism, discovers that the fallen world within everybody, in their crisis and their obsessions, in the destructive consequences that communism has left.

Besfort becomes Orpheus and Rovena Eurydice. Substitution by substitution, we come to the significance of a past and present. The selection of several mythical elements provides the diving of the story in a mythical atmosphere:

The sign as we know, has the capacity to expand or change the concepts.

The sign pushes away the time and here we are face to face with the thing, in the ideological and emotional heart of the phenomenon.

The meaning of all this intimacy and death insists over and over that Orpheus will always be dead within Eurydice (as Rilke suggests in Sonnet for Orpheus). Is this a novel human practice in favor of death? What has really happened? Why do we never learn the truth? And how can we approach the truth?

But... the fact that the intelligence is not the most subtle, powerful, appropriate, instrument for grasping the truth. The truth is only one more reason in favor of starting with the intelligence rather than with intuitions of the unconscious or with unquestioning faith in our premonitions. It is life which, little by little, case by case, allows us to realize that what is most important for our heart, or to our minds, is taught not by reasoning but by other powers. And it is the intelligence itself, which recognizing other superiority, uses its reasoning in order to abdicate in their favor and accepts the role of collaborator and servant. (Proust, 1989, p.7)

There is actually a multiplicity of strategies to approach the truth in "The accident", through which we can maximize the number and diversity of meanings, meanings possible...

The author seeks to provide a analysis of the unknown, of the incomprehensive, an analysis which is unusual for comprehensibility, itself. It never finally speaks the last word.

(Literature) ... reminds us that reading is, or may be an act of creation. What happens when we read literature is that the author knows and what we know form, in combination, something new, a third quantity, which we may or may not want to call knowledge. This new quantity is born in the moment of reading itself, as does Martha Nussbaum, in Love's Knowledge says "love can crystallize in a moment of perception." (Nussbaum, 1992, p. 267), "love is not a structure in the heart waiting to be discovered". There are things waiting to be discovered in a novel or poem, or play and with luck we shall discover them. Similarly we bring our affective and intellectual lives to the act of reading any text we care about. But the meeting produces something else again, or does literature's best moments. (Wood, 2005, p.153)

This text is a meeting of cultural values and social and poetic meaning-from which-derived so painful allegories.

\section{References}

Bakhtin, M.M., 1984, The Dialogical Imagination, Tx: University of Texas Press

Compagnon, A., 2004, Literature, Theory and Common Sense, Princeton and Oxford

Nussbaum, M., 1992, Love's Knowledge, Oxford University Press, Oxford

Proust, M., 1989, A la recherche du temps perdu, Paris: Gallimard, vol IV, trans. by Peter Collier, 2002, The Fugitive. Penguin, London

Wood, M., 2005, Literature and the Taste of Knowledge, Cambridge University Press, Cambridge. 